\title{
Lithospheric delamination in the core of Pangea: Sm-Nd insights
}

\author{
from the Iberian mantle
}

\author{
Gabriel Gutiérrez-Alonso¹, J. Brendan Murphy², Javier Fernández-Suárez³ , Arlo B. Weil', M. Piedad Franco ${ }^{1}$, and \\ J. Carlos Gonzalo' \\ 1Departamento de Geología, Universidad de Salamanca, Salamanca 37008, Spain \\ 2Department of Earth Sciences, St. Francis Xavier University, Antigonish, Nova Scotia B2G 2W5, Canada \\ ${ }^{3}$ Departamento de Petrología y Geoquímica, Universidad Complutense and IGE-CSIC (Instituto de Geología Económica, Consejo \\ Superior de Investigaciones Científicas), Madrid 28040, Spain \\ 4Department of Geology, Bryn Mawr College, Bryn Mawr, Pennsylvania 19010, USA
}

\begin{abstract}
Delamination of continental lithosphere in the core of active collisional orogens is a wellestablished process; however, evidence for its occurrence in ancient orogenic belts is less obvious. The contrasting Sm-Nd isotopic signature between pre- and post-Middle Permian mantle-derived mafic rocks from under the Iberian Massif suggests that most, but not all, of the subcontinental lithospheric mantle (SCLM) was replaced in latest Carboniferous to Permian time. Mantle replacement happened during and after the bending of the Variscan orogenic belt into the horseshoe-shaped Iberian-Armorican orocline. Delamination of thickened continental lithosphere in the core of the orocline triggered replacement of the ancient SCLM, thereby providing an explanation for the contrasting Sm-Nd isotopic characteristics of pre- and post-Middle Permian mafic rocks.
\end{abstract}

\section{INTRODUCTION}

The long-term relationship and interaction between continental crust and its underlying subcontinental lithospheric mantle (SCLM) is one of the key elements in understanding lithospheric-scale tectonic processes and crustal evolution through time. The SCLM can underlie a region for a long period of time, during which major geodynamic processes can occur and produce episodes of magmatism that may tap into similar mantle and/or crustal sources (Murphy and Dostal, 2007). Alternatively, some major tectonic events can modify the nature of, or replace, the existing SCLM, and thus change the isotopic signature of the source of future juvenile crust. Delamination in the upper plate associated with rollback, tearing, and breaking off of a subducted slab is well documented (Davies and von Blanckenburg, 1995). In contrast, in collisional settings, lithospheric delamination in the lower plate is well established in the root of modern orogens (e.g., Gvirtzman, 2002; Knapp et al., 2005), but identifying such events in older collisional orogens, such as the Variscan orogen, is more problematic

Delamination should result in the replacement of older SCLM that underlies orogenic crust with more buoyant asthenospheric mantle. This replacement should produce a change in the isotopic composition of the underlying mantle, and therefore mantle melts generated before and after delamination should have different isotopic signatures. In addition, the isotopic signature of igneous rocks generated coevally with delamination may record the various possible interactions among the older and younger mantles and the lower crust during the delamination event. Therefore, a hypothesized delamination event can be tested by comparing the isotopic evolution of mantle-derived magma before and after the putative event. events described in text.
The Iberian Massif (Fig. 1) has relatively abundant mantle-derived mafic volcanic, subvolcanic, and plutonic rocks that collectively span more than 500 m.y. of time (560-10 Ma). $\mathrm{Sm}-\mathrm{Nd}$ isotopic systematics provide robust criteria for tracing mantle evolution if the isotopic compositions of mantle-derived magmas produced before and after major tectonic events are compared. In this paper we use $\mathrm{Sm}-\mathrm{Nd}$ isotopic data from a suite of rocks from the Iberian Massif to compare the composition of the SCLM before and after the late Paleozoic Variscan orogeny that led to the amalgamation of Pangea.

It has been proposed that, following continental collision and extensional collapse (Bea et al., 2006), lithospheric delamination took place

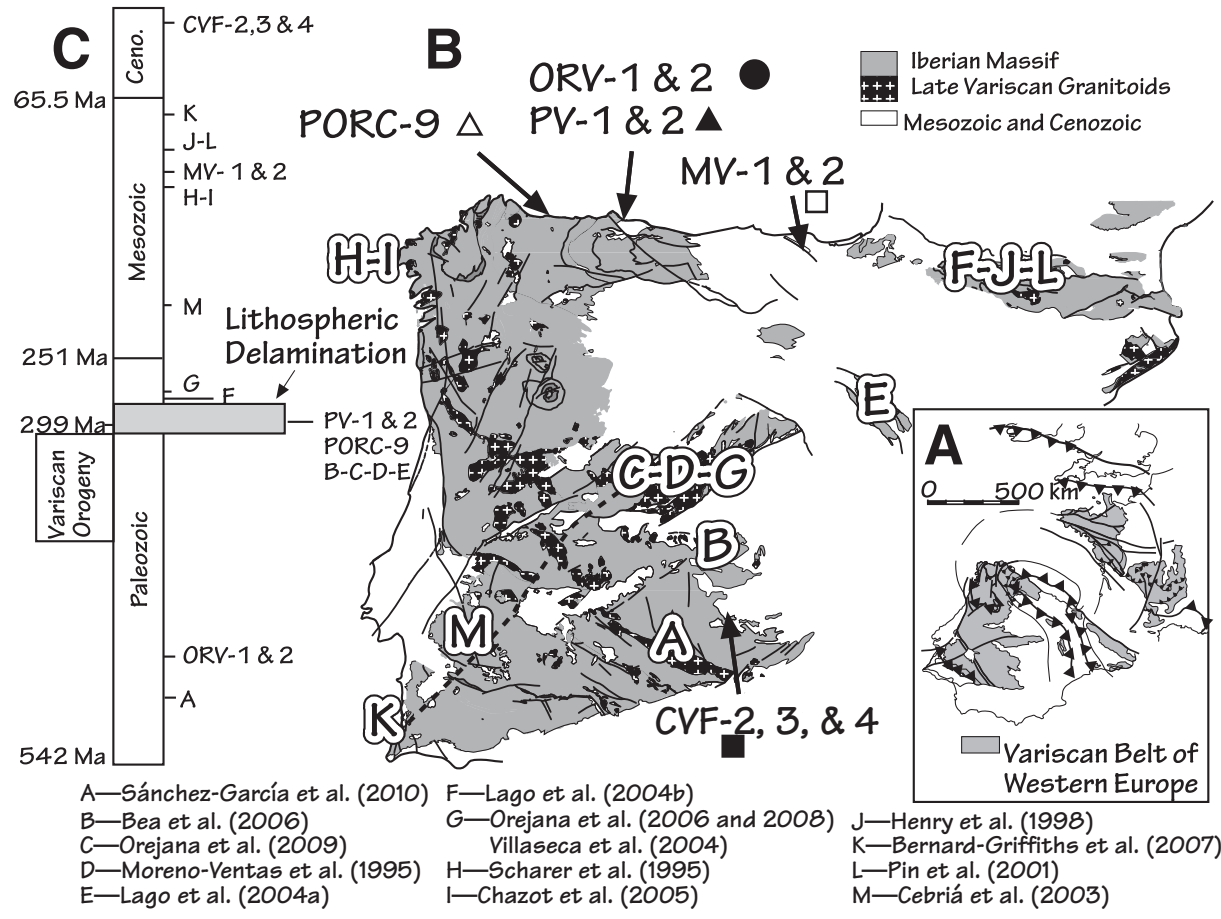

Figure 1. A: Position of Iberia within Iberian-Armorican arc. B: Geologic sketch of Iberia indicating location of samples from this study (Ordovician volcanics-black circles; Early Permian volcanics-black triangles; mafic igneous rocks-white triangles; Cretaceous volcanics-white squares; recent volcanics—black squares) as well as locations of other data used from literature (References cited in figure are in Table DR2; see footnote 1). Symbols for studied samples are as in Figure 2 and Figure DR1. C: Timeline representing tectonic 
under the Iberian portion of the Variscan orogenic belt between ca. 305 and $285 \mathrm{Ma}$ (Fernandez-Suarez et al., 2000; Gutiérrez-Alonso et al., 2004; Weil et al., 2010). If this is correct, mantlederived magmas generated before and after the delamination event should have contrasting $\mathrm{Nd}$ isotopic signatures; mafic rocks formed prior to delamination should have signatures consistent with genesis from an old SCLM, whereas mafic rocks generated after the delamination process was completed should have more juvenile signatures. Igneous rocks formed during the $\sim 20$ m.y. interval in which delamination occurred (Weil et al., 2010) may have a mixed (old SCLM or new asthenospheric mantle) signature.

This study combines pertinent data from the literature (Table DR1 in the GSA Data Repository ${ }^{1}$ ) with new major and trace element and Sm-Nd data from selected mafic rocks from across Iberia (Table DR2) in order to constrain large-scale mantle evolution under the Iberian Massif during the Paleozoic.

\section{GEOLOGIC SETTING}

The Iberian Massif (Fig. 1) is underlain by Proterozoic Gondwanan basement, which creates the foundation for an Ediacaran subduction-related basin and a Paleozoic passive margin sequence that is characteristic of the northern Gondwana margin (Fernández-Suárez et al., 2002; Murphy et al., 2008). During the Carboniferous, the outermost margins of the Iberian Massif were intensely folded, metamorphosed, imbricated, and overthrust by ophiolites during the Variscan collision between Gondwana and Laurentia (Martínez Catalán et al., 2009). Variscan syntectonic magmatism began ca. $350 \mathrm{Ma}$ in the hinterland of the orogen (Perez Estaun and Bea, 2004). Post-tectonic magmatism peaked ca. 305-295 Ma, when mafic and granitoid magmas occurred in both the internal zones and the foreland fold-and-thrust belt of the orogen (Fernandez-Suarez et al., 2000) (Fig. 1B).

Post-tectonic magmatism virtually ended by Early Permian time (Fernandez-Suarez et al., 2000) and was followed by a minor magmatic episode, mainly in the form of dike swarms and volcanics, the ages of which range from ca. 270 to $255 \mathrm{Ma}$ (Lago et al., 2004; Orejana et al., 2006). Some of these dikes contain lower crustal granulitic xenoliths (Villaseca et al., 1999). U-Pb dating of zircons extracted from those xenoliths indicates that the lower crust

${ }^{1}$ GSA Data Repository item 2011050, Table DR1 (isotopic data from the literature used in this study); Table DR2 (location of the samples used from the literature); analytical techniques and geochemical composition of the studied sample; Figure DR1 (chondritenormalized REE diagram for the studied samples); and references cited in Figure 1, is available online at www.geosociety.org/pubs/ft2011.htm, or on request from editing@geosociety.org or Documents Secretary, GSA, P.O. Box 9140, Boulder, CO 80301, USA. underwent granulitization between ca. 310 and 285 Ma (Fernández-Suárez et al., 2006). Subsequent ca. $200 \mathrm{Ma}$ basalts and mafic dikes are interpreted as local examples of the Central Atlantic Magmatic Province (Cebriá et al. 2003). Cretaceous alkaline magmatism occurred in the West European Atlantic platform and the rocks are exposed in isolated outcrops, mostly in the Pyrenees and the southwest Iberian Peninsula. This magmatism is attributed to opening of the Atlantic Ocean and the Bay of Biscay.

The most recent magmatic event recorded in the Iberian Massif is related to post-Alpine (younger than $10 \mathrm{Ma}$ ) extension, which produced the Calatrava volcanic field (Lopez-Ruiz et al., 1993).

\section{GEOCHEMISTRY AND Sm-Nd ISOTOPIC COMPOSITION}

Previous geochemical and $\mathrm{Sm}-\mathrm{Nd}$ isotopic studies have been conducted on many magmatic suites from the Iberian Massif (compiled in Table DR1). New data are provided for suites that are underrepresented in the existing Iberian data set (Fig. 1; Table DR2; for analytical methods, see the Data Repository).

Cambrian-Ordovician basalts (Fig. DR1A) display strong light rare earth element (LREE) enrichment, with high $\mathrm{La} / \mathrm{Yb}_{\mathrm{n}}(\sim 20-30)$ and no significant $\mathrm{Eu}$ anomaly, which together with their high $\mathrm{Nb} / \mathrm{Y}$ values suggest derivation from an enriched lherzolite mantle source (Murphy et al., 2008).

The latest Carboniferous-Early Permian basalts and plutonic mafic rocks (Fig. DR1B) have geochemical signatures broadly similar to those of Cambrian-Ordovician basalts, but they display negative $\mathrm{Nb}-\mathrm{Ti}$ anomalies (Fig. DR1B.2) that suggest contamination by either en route crustal or premelting subductionmodified components.

In addition, the Middle to Late Permian, Cretaceous, and Miocene mafic rocks (Fig. DR1C) are characterized by moderate to strong LREE enrichment (chondrite-normalized La/Yb 1015) and no Eu anomaly. The mantle-normalized multielement trace element patterns for these youngest suites (e.g., lack of $\mathrm{Nb}$-Ti negative anomalies) suggest contamination during ascent through the crust or derivation from a mantle source that was contaminated by an earlier episode of subduction.

Pre-Variscan (Cambrian and Ordovician) mantle-derived mafic rocks have $\varepsilon_{\mathrm{Nd}(\mathrm{t})}$ values that range from +1.0 to +5.0 (lower than the contemporary depleted mantle) and $\mathrm{T}_{\mathrm{DM}}$ (depleted mantle model) ages that range from ca. 0.9 to 1.1 Ga (Fig. 2). These rocks exhibit no evidence of significant crustal contamination (e.g., lack of negative Nb-Ta anomalies; Fig. DR1A) and their Sm-Nd isotopic signature is interpreted to reflect derivation from an ancient SCLM enriched between 0.9 and 1.1 Ga (Murphy et al., 2008). These Sm-Nd isotopic characteristics are typical of the SCLM along much of the northern Gondwanan margin (Murphy and Dostal, 2007), and thus are interpreted to reflect the composition of the SCLM beneath the Iberian Massif during the early Paleozoic.

The most primitive mafic rocks of Pennsylvanian-Early Permian age (Orejana et al., 2009) have $\mathrm{T}_{\mathrm{DM}}$ ages and $\varepsilon_{\mathrm{Nd}(\mathrm{t})}$ values comparable to those of the Ordovician basalts (i.e., $\mathrm{T}_{\mathrm{DM}}$ ca. 1.0 Ga and $\varepsilon_{\mathrm{Nd}(t)}+1.0$ to +2.5 ) (Fig. $2 \mathrm{~B}$ ), suggesting that those Pennsylvanian-Early Permian volcanic rocks were derived from the same (or very similar) SCLM.

More generally, however, PennsylvanianEarly Permian mafic volcanic and plutonic rocks exhibit a larger variability of $\mathrm{Nd}$ isotope compositions (Figs. 2A-2C) with $\varepsilon_{\mathrm{Nd}(t)}$ values between -7.5 and +2.5 (median value of -1.9 ). Most (i.e., $70 \%$ ) of the data have $\varepsilon_{\mathrm{Nd}(t)}$ values between +1.0 and -3.0 and $\mathrm{T}_{\mathrm{DM}}$ ages that range from 0.95 to $1.5 \mathrm{Ga}$ (median value of $1.2 \mathrm{Ga}$ and $70 \%$ of data between 0.95 and $1.3 \mathrm{Ga}$ ).

The lower $\varepsilon_{\mathrm{Nd}(\mathrm{t})}$ values and higher $\mathrm{T}_{\mathrm{DM}}$ ages for most Pennsylvanian-Early Permian mafic rocks (compared to those of Cambrian-Ordovician basalts) are attributed to contamination by a crustal component, consistent with their negative $\mathrm{Nb}$ - $\mathrm{Ti}$ anomalies and the overlap in $\varepsilon_{\mathrm{Nd}(\mathrm{t})}$ and $\mathrm{T}_{\mathrm{DM}}$ of these rocks with those of lower crustal granulite xenoliths from the Iberian Massif (Villaseca et al., 1999).

The Middle to Late Permian magmatism (ca. 270-255 Ma) is represented mainly by mafic dikes that contain entrained ultramafic xenoliths (Orejana et al., 2006). The mafic rocks forming those dikes (Figs. 2A-2C) yield $\varepsilon_{\mathrm{Nd}(t)}$ values between -1.0 and +7.0 and $\mathrm{T}_{\mathrm{DM}}$ ages ranging from 0.36 to $0.97 \mathrm{Ga}$. Ultramafic xenoliths have $\varepsilon_{\mathrm{Nd}(t)}$ values close to +6.0 and $\mathrm{T}_{\mathrm{DM}}$ ages of ca. $0.6-0.8 \mathrm{Ga}$. As a whole, this range of $\mathrm{Nd}$ isotopic compositions suggests a mixture of the old ca. 0.9-1.1 Ga SCLM and a new (juvenile) mantle of late Paleozoic age. To our knowledge, these are the oldest mafic rocks in Iberia with $\mathrm{Sm}-\mathrm{Nd}$ isotopic compositions typical of the contemporaneous depleted mantle. The range of $\mathrm{Nd}$ isotopic compositions in Middle to Late Permian mafic rocks can be interpreted to reflect either (1) mixing of melts extracted simultaneously from older and younger SCLM or (2) a local mantle heterogeneity at the time of magma generation. In either case, the $\mathrm{Nd}$ isotopic variability suggests the coexistence of an old and juvenile SCLM at the time of generation.

The ca. 200 Ma CAMP magmatism includes a suite of mafic dikes with $\varepsilon_{\mathrm{Nd}(t)}$ ranging from -2.1 to +1.6 . The $\mathrm{T}_{\mathrm{DM}}$ ages of 1097 to $1670 \mathrm{Ga}$ (median $1274 \mathrm{Ga}$ ) are interpreted to reflect a ca. 1.3 Ga mantle metasomatic event (Cebriá et al., 2003). Mesozoic and Cenozoic mafic rocks 


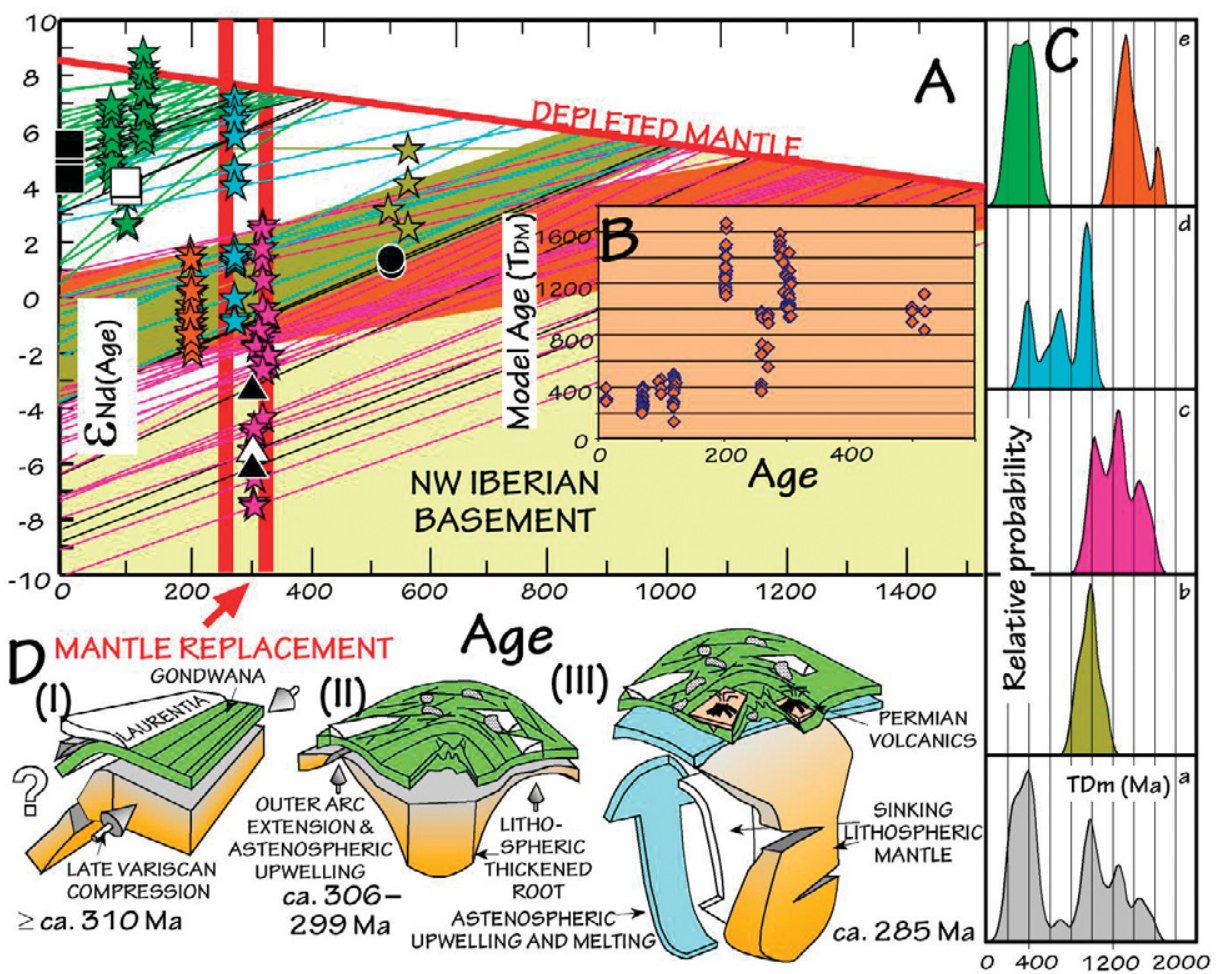

Figure 2. Isotopic data and conceptual illustration of mantle replacement in core of Pangea. A: $\mathrm{Sm}$-Nd isotopic data for studied rocks of northwest lberia. $\varepsilon_{\mathrm{Nd}(t)}$ versus age plot. Stars represent data used (colored as in histograms in C). B: Age versus model age plot of studied samples. Depleted mantle model $\left(\mathrm{T}_{\mathrm{DM}}\right)$ ages are calculated using modern depleted mantle composition (DePaolo, 1988). C: Model age probability plots grouped as: a-complete data set; b-pre-Variscan data; c-Pennsylvanian-Early Permian samples; d-Middle to Late Permian rocks; e-Mesozoic and Cenozoic mafic rocks. D: Schematic illustration of relationship between postorogenic oroclinal bending and lithospheric delamination (Gutiérrez-Alonso et al., 2004). I-Linear belt resulting from Variscan collision. II-Oroclinal postcollision bending caused lithospheric stretching in outer arc and thickening beneath inner arc. III-Delamination and replacement of sinking lithosphere by upwelling asthenospheric mantle.

(Figs. 2A-2C) have $\varepsilon_{\mathrm{Nd}(t)}$ values that range from +2.5 to +8.8 (median +6.5 ) and much younger $\mathrm{T}_{\mathrm{DM}}$ ages that range from 0.14 to $0.49 \mathrm{Ga}$ (median $0.37 \mathrm{Ga}$ ). These values suggest negligible crustal contamination and are interpreted to reflect derivation from a SCLM source that is significantly younger than the SCLM source of both the Cambrian-Ordovician and the Pennsylvanian-Early Permian mafic rocks, but similar to that of some of the Middle to Late Permian basalts. In addition, Grange et al. (2010) reported an Hf isotopic composition in zircons from the ca. $70 \mathrm{Ma}$ alkaline rocks of southwest Portugal that is consistent with mantle extraction ages between ca. 0.3 and $0.5 \mathrm{Ga}$.

\section{DISCUSSION}

Cambrian-Ordovician mafic rocks have an $\mathrm{Sm}-\mathrm{Nd}$ signature that is consistent with derivation from an old SCLM, enriched ca. 0.91.1 Ga, that has underlain the region since at least that time. The most isotopically primitive Pennsylvanian-Early Permian mafic rocks (ca. 310-290 Ma) show Nd isotopic compositions comparable to those of the Cambrian- values (median value of +6.5 ) and Paleozoic, mostly younger than $0.45 \mathrm{Ga}, \mathrm{T}_{\mathrm{DM}}$ ages.

The contrast in the $\mathrm{Sm}-\mathrm{Nd}$ isotopic signature between pre-Middle to Late Permian and post-Middle to Late Permian mafic rocks constrains the age of the oldest pulse of regionalscale juvenile magmatism and suggests that the SCLM under the Iberian Massif was to a large extent replaced soon after Early Permian time (Figs. 2A and 2D). Although this new SCLM provided the source for the Cretaceous and Miocene magmatic events, the isotopic signature of the ca. 200 Ma mafic magmas suggests that not all the older SCLM was replaced

Voluminous and widespread ca. 300 Ma late Variscan magmatism was the culmination of an extended period of episodic igneous activity that occurred during and after the Variscan collision that began $\sim 350$ m.y. ago in western Europe (Martínez Catalán et al., 2009). The origin of the heat source that triggered late Variscan magmatic activity has been variously attributed to radiogenic heat production in a thickened crust (Bea et al., 2003), a mantle plume (Pinarelli and Rottura, 1995), or to postorogenic lithospheric delamination (Fernandez-Suarez et al., 2000).

This magmatic activity as well as the granulitization of the lower crust (Fernández-Suárez et al., 2006; Villaseca et al., 1999) is coeval with the mantle replacement event outlined here, suggesting that asthenospheric upwelling and concomitant mafic underplating may have provided the dominant heat source for the ca. $300 \mathrm{Ma}$ magmatism (Fernandez-Suarez et al., 2000). As this magmatic event occurred at orogenic scale in a short period of time $(<20$ m.y. $)$, it is not likely to have been caused either by a mantle plume or by enhanced radiogenic heat production in a thickened crust.

Coevally with the late Variscan magmatic episode, the Iberian Massif underwent a firstorder tectonic event that included lithosphere buckling around a vertical axis that gave rise to the orocline known as the Iberian-Armorican arc (Gutiérrez-Alonso et al., 2008). Paleomagnetic evidence (Weil et al., 2001) suggests that the orocline was developed between ca. 310 and $300 \mathrm{Ma}$ (Weil et al., 2010), coevally with the magmatism due to extension in the outer arc of the orocline that started in the Pennsylvanian. Subsequent magmatism related to the sinking thickened root in the core of the orocline was Early Permian.

Figure 2D depicts the proposed mechanism whereby ca. 310-300 Ma lithospheric-scale oroclinal buckling of a linear Variscan orogen would have resulted in lithospheric extension in the outer arc and thickening of the lithospheric root and the onset of delamination in the core of the orocline. The extension in the outer arc and the delamination under the core of the orocline would have triggered the asthenospheric 
upwelling that provided the heat responsible for late Variscan magmatism.

By ca. 310-305 Ma the extension in the outer arc, and, by ca. $300 \mathrm{Ma}$ the delamination of the lithospheric thickened root, caused the upwelling asthenospheric mantle that provided the heat needed to trigger melting of the SCLM and the lower crust. The late Variscan mafic rocks and their Nd isotopic signatures are consistent with a scenario (Fig. 2D) in which melts were derived from old SCLM and the lower crust, while upwelling asthenospheric mantle provided the thermal spike needed to trigger melt production.

By Middle to Late Permian time, foundering of the delaminated continental root would have enhanced asthenospheric upwelling and the replacement of the older, sinking SCLM (Fig. 2D). The Middle to Late Permian mafic rocks have isotopic signatures that suggest mixed derivation from old SCLM and new upwelling asthenospheric mantle. Cretaceous and Miocene mafic rocks were derived from melting of this new mantle and show no evidence for a significant participation of the older SCLM in their genesis, owing to either almost complete replacement or because it was rendered infertile by repeated episodes of melting. The above hypothesis addresses both the cause and effect relationships and the penecontemporaneous nature of oroclinal development, widespread mafic and felsic magmatism, and the changes in $\mathrm{Sm}-\mathrm{Nd}$ isotopic characteristics of mantle-derived mafic rocks across the Iberian Massif. Furthermore, this hypothesis may provide insights into the processes that shape the tectonic stability of the mantle lithosphere through time and the understanding of its role in the genesis of ubiquitous curved mountain belts.

\section{ACKNOWLEDGMENTS}

Gutiérrez-Alonso, Piedad Franco, and Carlos Gonzalo were supported by project ODRE II no. CGL2009-1367, from the Spanish Ministry of Science and Innovation. Fernández-Suárez was supported by project CONSOLIDER CGL2007-65338-C02-01/ BTE. Gutiérrez-Alonso also received funding from the Mobility Program grant PR2007-0475. Murphy acknowledges the support of the Natural Sciences and Engineering Research Council (NSERC, Canada) through Discovery and Research Capacity Development grants. We thank Ulf Linnemann and two anonymous reviewers for constructive reviews. This is a contribution to International Geological Correlation (IGCP) Programme 574, "Bending and Bent Orogens, and Continental Ribbons."

\section{REFERENCES CITED}

Bea, F., Montero, P., and Zinger, T., 2003, The nature, origin, and thermal influence of the granite source layer of central Iberia: Journal of Geology, v. 111, p. 579-595, doi: 10.1086/376767.

Bea, F., Montero, P.G., Gonzalez-Lodeiro, F., Talavera, C., Molina, J.F., Scarrow, J.H., Whitehouse, M.J., and Zinger, T., 2006, Zircon thermometry and $\mathrm{U}-\mathrm{Pb}$ ion-microprobe dating of the gabbros and associated migmatites of the Variscan Toledo anatectic complex, central Iberia: Geological Society of London Journal, v. 163, p. 847855, doi: 10.1144/0016-76492005-143.

Cebriá, J.M., López-Ruiz, J., Doblas, M., Martins, L.T., and Munha, J., 2003, Geochemistry of the Early Jurassic Messejana-Plasencia dyke (Portugal-Spain); Implications on the Origin of the Central Atlantic Magmatic Province: Journal of Petrology, v. 44, p. 547-568.

Davies, J.H., and von Blanckenburg, F., 1995, Slab breakoff: A model of lithosphere detachment and its test in the magmatism and deformation of collisional orogens: Earth and Planetary Science Letters, v. 129, p. 85-102, doi: 10.1016/0012-821X(94)00237-S.

DePaolo, D.J., 1988, Neodymium isotope geochemistry: An introduction: New York, Springer Verlag, 187 p.

Fernández-Suárez, J., Dunning, G.R., Jenner, G.A., and Gutierrez-Alonso, G., 2000, Variscan collisional magmatism and deformation in NW Iberia: Constraints from U-Pb geochronology of granitoids: Geological Society of London Journal, v. 157, p. 565-576, doi: 10.1144/ jgs.157.3.565.

Fernández-Suárez, J., Alonso, G.G., and Jeffries, T.E., 2002, The importance of along-margin terrane transport in northern Gondwana: Insights from detrital zircon parentage in Neoproterozoic rocks from Iberia and Brittany: Earth and Planetary Science Letters, v. 204, p. 7588, doi: 10.1016/S0012-821X(02)00963-9.

Fernández-Suárez, J., Arenas, R., Jeffries, T.E., Whitehouse, M.J., and Villaseca, C., 2006, A U-Pb study of zircons from a lower crustal granulite xenolith of the Spanish central system: A record of Iberian lithospheric evolution from the Neoproterozoic to the Triassic: Journal of Geology, v. 114, p. 471-483, doi: $10.1086 / 504180$.

Grange, M., Scharer, U., Merle, R., Girardeau, J., and Cornen, G., 2010, Plume-lithosphere interaction during migration of cretaceous alkaline magmatism in SW Portugal: Evidence from $\mathrm{U}-\mathrm{Pb}$ ages and $\mathrm{Pb}-\mathrm{Sr}-\mathrm{Hf}$ isotopes: Journal of Petrology, v. 51, p. 1143-1170, doi: 10.1093/ petrology/egq018.

Gutiérrez-Alonso, G., Fernández-Suárez, J., and Weil, A.B., 2004, Orocline triggered lithospheric delamination, in Weil, A.B., and Sussman, A., eds., Paleomagnetic and structural analysis of orogenic curvature: Geological Society of America Special Paper 383, p. 121-131.

Gutiérrez-Alonso, G., Fernandez-Suarez, J., Weil, A.B., Murphy, J.B., Nance, R.D., Corfu, F., and Johnston, S.T., 2008, Self-subduction of the Pangaean global plate: Nature Geoscience, v. 1, p. 549-553, doi: $10.1038 /$ ngeo 250 .

Gvirtzman, Z., 2002, Partial detachment of a lithospheric root under the southeast Carpathians: Toward a better definition of the detachment concept: Geology, v. 30, p. 51-54, doi: 10.1130/0091-7613(2002)030<0051:PDOALR $>2.0 . \mathrm{CO} ; 2$.

Knapp, J.H., Knapp, C.C., Raileanu, V., Matenco, L., Mocanu, V., and Dinu, C., 2005, Crustal constraints on the origin of mantle seismicity in the Vrancea zone, Romania: The case for active continental lithospheric delamination: Tectonophysics, v. 410, p. 311-323, doi: 10.1016/j tecto.2005.02.020.

Lago, M., Arranz, E., Pocovi, A., Gale, C., and GilImaz, A., 2004, Permian magmatism and basin dynamics in the southern Pyrenees: A record of the transition from late Variscan transtension to early Alpine extension, in Wilson, M., et al., eds., Permo-Carboniferous magmatism and rifting in Europe: Geological Society of London Special Publication 223, p. 439-464, doi: 10.1144/GSL.SP.2004.223.01.19.

Lopez-Ruiz, J., Cebria, J.M., Doblas, M., Oyarzun, R., Hoyos, M., and Martin, C., 1993, Cenozoic intraplate volcanism related to extensional tectonics at Calatrava, central Iberia: Geological Society of London Journal, v. 150, p. 915-922, doi: 10.1144/gsjgs.150.5.0915.

Martínez Catalán, J.R., and 16 others, 2009, A rootless suture and the loss of the roots of a mountain chain: The Variscan Belt of NW Iberia: Comptes Rendus Geoscience, v. 341, p. 114 126, doi: 10.1016/j.crte.2008.11.004.

Murphy, J.B., and Dostal, J., 2007, Continental mafic magmatism of different ages in the same terrane: Constraints on the evolution of an enriched mantle source: Geology, v. 35, p. 335338, doi: 10.1130/G23072A.1.

Murphy, J.B., Gutierrez-Alonso, G., Fernandez-Suarez, J., and Braid, J.A., 2008, Probing crustal and mantle lithosphere origin through Ordovician volcanic rocks along the Iberian passive margin of Gondwana: Tectonophysics, v. 461, p. 166-180, doi: 10.1016/j.tecto.2008.03.013.

Orejana, D., Villaseca, C., and Paterson, B.A., 2006, Geochemistry of pyroxenitic and hornblenditic xenoliths in alkaline lamprophyres from the Spanish Central System: Lithos, v. 86, p. 167196, doi: 10.1016/j.lithos.2005.03.014.

Orejana, D., Villaseca, C., Perez-Soba, C., LopezGarcia, J.A., and Billstrom, K., 2009, The Variscan gabbros from the Spanish Central System: A case for crustal recycling in the subcontinental lithospheric mantle?: Lithos, v. 110 p. 262-276, doi: 10.1016/j.lithos.2009.01.003.

Perez Estaun, A., and Bea, F., 2004, Macizo Iberico, in Vera, J.A., ed., Geología de España: Madrid, SGE-IGME, p. 19-230.

Pinarelli, L., and Rottura, A., 1995, Sr and Nd isotopic study and $\mathrm{Rb}-\mathrm{Sr}$ geochronology of the Bejar Granites, Iberian Massif, Spain: European Journal of Mineralogy, v. 7, p. 577-589.

Villaseca, C., Downes, H., Pin, C., and Barbero, L., 1999, Nature and composition of the lower continental crust in central Spain and the granulite-granite linkage: Inferences from granulitic xenoliths: Journal of Petrology, v. 40, p. 14651496, doi: 10.1093/petrology/40.10.1465.

Weil, A.B., van der Voo, R., and van der Pluijm, B.A., 2001, Oroclinal bending and evidence against the Pangea megashear: The Cantabria-Asturias arc (northern Spain): Geology, v. 29, p. 991994, doi: 10.1130/0091-7613(2001)029<0991 :OBAEAT>2.0.CO;2.

Weil, A., Gutierrez-Alonso, G., and Conan, J., 2010 New time constraints on lithospheric-scale oroclinal bending of the Ibero-Armorican Arc: A palaeomagnetic study of earliest Permian rocks from Iberia: Geological Society of London Journal, v. 167, p. 127-143, doi: 10.1144/0016 -76492009-002. 